would give insertion to a letter containing the facts and arguments on which a motion for the suppression of the Journal, as at present conducted, will be based, so that these facts and arguments might be deliberately consirlered by the members of the Association prior to the next general meeting. The editor replies that mine is an "invitation to us to perform the Japanese operation of the "happy dispatch," and reserves his right to exercise editorial judginent on the document before publish ing it.

The Japanese operation of the "bappy dispatch" is a speedy and effectnal method of self destruction; and the editor of the British Medical Journal is, therefore, of opinion that his pub. lication could not survive the appearance of one single letter containing the facts and arguments that may be adducel in favour of its suppression. I hail with great satisfaction an admission that affords evidence of increasing discernment as well as of praiseworthy candour.

We must not, however, be too sure that the editor perceives the entire force of the sentence he has penned. It is one of his babits to draw illustrations from subjects with which his acquaintance is imperfect, and thus to convey to his reulers a meaning very different, from his own. Formerly you, Sir, were "Tartuffe." In time, a line of conduct of wich the editor disapproved became "Trurtuffism." I conld not refrain from addressing him on the subject of the last old compound. I in quired of what language it formed part, and how it should be accented and pronounced. I took occasion to point out that, if he were acquainted with the writings of Moliere, he would know that Tartuffe was a base and wicked man-systematically a hypocrite for the attainment of base and wicked ends; and that he would shrink from applying the name of such a one as an epithet descriptive of gentlemen who differed from him in opinion. My letter was not published, and no information about "Tartuffism" was afforded me. But the editor probably made inquiries about Molière, and was shocked, as he could hardly fail to be, at discovering the meaning of the words he had used. From that time "Tartuffe" and its compounds have ceased to adorn his pages. Possibly the "happy dispatch" may now fall into similar disuse.

About the proposed "exercise of editorial judgment" there is much to be said on koth sides. But it sfems absurd that the editor, an officer of the Association, should be in a position to close the Journal to one of the members $w$ ho wishes to address the others upon a subject of vital importance to the whole body. In point of fact, the very existence of the Journal involves anomalies of which this is only one of the least. I am, Sir, your most obedient servant,

Stroud, Oct. 30th, 1861 Robt. B. Carter, F.R.C.S.

\section{VOLUNTERR S URGEONS.} To the Editor of THE LANCET.

SrR, - It wonld be well if some general regulation were issued respecting medical officers of volunteers. At present, things are in a state of chavs. Some regiments have honorary assistant. surgeons only; others have surgeons only on the staff of the battalion; while others have surgeons on the staff, assistantsurgeons attached to corps, and honorary assistant surgeons attached to companies-all forming part of the same battalion. I have seen as many as six medical officers fall-in on a regimental inspection, quite contrary to the regulations for the army, and certainly ridiculous. I presume that a volunteer regiment under arms is supposed in every way to be appointed and constructed as one of the line or militia: if so, the only medical officers that should fall-in would be those on the staff and these officers should also attend in regularity the county prize meetiugs, \&c., which the senior officer should arrange. I am, Sir, your obedient servant,

V. R.

\section{"A QUIVER FULL OF THEM." To the Editor of THE LANCET.}

SIR, - The curious in statistics amongst your readers may gather instruction from an instance of fecundity $I$ believe an usual in the human female.

The case, of which I copy the data from my obstetric register, is that of a lady about thirty years of age, of middle stature, well nourished, bealthy, and of sanguine complexion. She married in 1859, and her first child was not born till after more than two years. In May, 1862, she was confined with twing, and in July of the following year with a triplet. On the 2nd of the present month she was safely delivered again of twins, making a grand total of eight, all born alive-the last seven within two years and a half. Certainly, if "increase of children is a nation's strength," my patient may claim to be considered one of our national bulwarks.

I am, Sir, yours, \&c.,

Wimpole-street, Nor. 1861. CRESWICK JACKSON, M.R.C.S,

\section{ABERDEEN}

(FROM OUR OWN CORRESPONDENT.)

The medical classes for the winter session commenced on the lst inst, which promises to be a successful one. The number of first year's students and those coming from other schools, is already more numerons than that of the preceding vear. The only change of personnel in the infirmary is the appointment of Dr. Williamson and Prof. Harvey to lecture on Clinical Medicine.

Dr. Williamson in his introductory lecture, after pronouncing a well-merited eulogium npon his distinguished predecessor, Dr. Kilgour, dwelt upm the much-agitated question of Medical Education, and on the importance of olinical study. Its aim is to train the senses and the mind, enriched by previous study, to correct observation, diagnosis, and treatment of disease. He alluded to the waste of time in attending unnecessary courses of systematic lectures at the expense of clinical study. The system which he (Dr. Williamson) and Prof. Harvey are to adopt is that of bedside instruction. Such remarks as cannot conveniently be communicated in the wards will be supplemented in the theatre. The pupils will be tasked by being made to work for themselves instead of being mere spectators.

The Rev. Mr. Mearns has been elected Assessor to the University Court instead of Dr. Kilgour, by a majority of 185 to 176 . This is to be regretted, for the sake of the University, in every respect. The newspapers characterize the whole transaction as the result of a "sectarian cabal." It behoves our graduates to see to it that the University Court be not turned into an ecclesiastical clique of obstructives.

The Garioch Medical Society, at its stated half.yearly meeting at Inverary, had under consideration a proposal from the Buchan Medical Society to join in an amalgamation of the differ. ent medical societies in the North to form a "North of Scotland Medical Association," with annual meetings in Aberdeen. the present societies, or branches, to continue their independent existence. The suhject has been deferred to the future consideration of the different societies. The union of such a large body as contemplated in the proposal cannot fail to be productive of public good, both in a scientific and in a public point of view.

In the meantime it is greatly to be wished that our branch s cieties shonld join in a movement for the purpose of clearing our atmosphere from those noxious elements that contaminate our towns. I have before me a pamphlet on "Manly Vigour : Words of Warning," \&c., which has been constantly advertised in our local papers for the last two years by a person who keeps: in our town one of those well-known shops of the Henery and Wilson pattern; and $I$ have no hesitation in saying that a more disgusting and demoralizing specimen of quack literature cannot be conceived. And yet the nuisance is constantly obtruded npon the notice of our young men and our young ladies, with the view of catching some unfortunate simpletons and of fleecing them under the seal of strict secrecy! What is the use of a Medical Act if it only serves to exrract money and annoy the legally qualified members of the profession, whilst it gives free scope to charlatans, - if any lad who is physically unfit to be a waiter or hairdresser's apprentice, or any sharper or blackleg, may assume the title of doctor, and insult the public by issuing publications charged with the vilest jargon of blasphemy? How is the public to know that the man is a swindler if his pretences are allowed to pass unchallenged by the medical faculty? It is true that medical practitioners gather a plentiful barvest from amongst the dupes and victims of those persons, in the shape of constitutional and hereditary diseases which come daily before us, but morally we are bound to protect the public. As citizens it is incumbent upon us, if possible, to rid our towns of those worthies; if not, at least to vindicate the hovour of our noble calling. 